\title{
Acute kidney injury and hepatitis associated with energy drink consumption: a case report
}

\author{
Raed Al Yacoub ${ }^{1,2^{*}}$, Debra Luczkiewicz ${ }^{3}$ and Christopher Kerr ${ }^{3}$
}

\begin{abstract}
Introduction: In the USA, energy drinks are commonly consumed among adults. The side effects of these drinks are not well studied but consumers have reported multiple adverse events to the US Food and Drug Administration including acute kidney injury and acute hepatitis.

Case presentation: A 62-year-old white woman presented with progressive weakness, fatigue, confusion, and delirium secondary to acute kidney injury and acute hepatitis associated with excessive energy drink use. Clinical improvement occurred with supportive care and discontinuation of energy drinks, with resolution of acute kidney injury and progressive improvement of liver function. The defined mechanism of injury is unknown but thought due to energy drink ingredients.

Conclusion: Multiple cases of energy drink-induced acute kidney injury or acute hepatitis are reported in the literature but this case is the first to report them simultaneously. Ingredients and presumed doses to cause these events are outlined in this case report.
\end{abstract}

Keywords: Energy drinks (EDs), Acute kidney injury (AKI), Acute hepatitis (AH)

\section{Introduction}

The consumption of energy drinks (EDs) increased from 2003 to 2016 in all age groups, including middle-aged (45 to 59 -year old) adults, whose consumption increased from $0.0 \%$ to $1.2 \%$ [1]. Many adverse event reports received by the US Food and Drug Administration from consumers through 2012 include psychiatric symptoms, arrhythmias, cardiac arrest, myocardial infarction, convulsions, and renal and liver impairment [2]. The mechanisms of injury are not well studied. The ingredients of EDs vary but most of them contain caffeine, L-carnitine, taurine, B vitamins, glucuronolactone, antioxidants, trace minerals, guarana, sucrose, Ginkgo biloba, and/or ginseng, some of which act as stimulants [3].
Previous case reports revealed acute kidney injury (AKI) induced by excessive ED consumption thought to be due to taurine, $[4,5]$ while others reported acute hepatitis (AH) attributed to niacin [6-8]. The doses that caused the injuries varied and are probably due to interactions with other ingredients.

\section{Case presentation}

A 62-year-old white woman who had been enrolled in hospice care for 4 months since discontinuing treatment for small cell carcinoma of the left lung presented to the hospice in-patient unit with several days' history of progressive confusion, fatigue, poor sleep, decreased intake,

\footnotetext{
* Correspondence: raedyacoub@yahoo.com

${ }^{1}$ Division of Hospital Medicine, Department of Internal Medicine, University

of Florida, 1230 SW 11th Ave, C405, Gainesville, FL 32601, USA

${ }^{2}$ Division of Geriatric and Palliative care, Department of Internal Medicine,

University at Buffalo, Buffalo, NY, USA

Full list of author information is available at the end of the article
}

(c) The Author(s). 2020 Open Access This article is distributed under the terms of the Creative Commons Attribution 4.0 International License (http://creativecommons.org/licenses/by/4.0/), which permits unrestricted use, distribution, and reproduction in any medium, provided you give appropriate credit to the original author(s) and the source, provide a link to the Creative Commons license, and indicate if changes were made. The Creative Commons Public Domain Dedication waiver (http://creativecommons.org/publicdomain/zero/1.0/) applies to the data made available in this article, unless otherwise stated. 
Table 1 Laboratory results

\begin{tabular}{|c|c|c|c|c|c|c|}
\hline Blood test & 2 months prior & Day 3 & Day 6 & Day 10 & 2 months after & Normal range \\
\hline$\overline{W B C} \times 10^{9} / L$ & 11 & 15.3 & 10.6 & 14.4 & 10 & $4-11$ \\
\hline $\mathrm{HgB}(\mathrm{g} / \mathrm{dL})$ & 14.2 & 15.6 & 13.3 & 13 & 15.2 & $12.5-15.5$ \\
\hline Platelet $\times 10^{9} / \mathrm{L}$ & 237 & 133 & 78 (mild clumping) & 133 & 237 & $150-450$ \\
\hline $\mathrm{sCr} .(\mathrm{mg} / \mathrm{dL})$ & 0.77 & 2.83 & 4 & 0.72 & 0.69 & $0.6-1.2$ \\
\hline BUN (mg/dL) & 13 & 18 & 85 & 23 & 12 & $8-27$ \\
\hline GFR (ml/minute/1.72 $\left.\mathrm{m}^{2}\right)$ & $>60$ & 17 & 11 & 89 & $>90$ & $>90$ \\
\hline Total bilirubin (mg/dL) & 0.3 & 0.5 & 0.5 & 0.8 & 0.3 & $0.3-1$ \\
\hline AST (U/L) & 39 & 4333 & 1129 & 70 & 30 & $13-39$ \\
\hline $\mathrm{ALT}(\mathrm{U} / \mathrm{L})$ & 30 & 2866 & 2928 & 812 & 41 & $7-52$ \\
\hline Alkaline phosphatase $(U / L)$ & 121 & 111 & 113 & 88 & 110 & 34-104 \\
\hline Ammonia ( $\mu \mathrm{mol} / \mathrm{L})$ & & & 149 & 89 & & $16-53$ \\
\hline
\end{tabular}

$A L T$ alanine aminotransferase, $A S T$ aspartate aminotransferase, $B U N$ blood urea nitrogen, $G F R$ glomerular filtration rate, $H g B$ hemoglobin, $s C r$. serum creatinine, $W B C$ white blood cell

nausea, and vomiting. On initial assessment her condition was thought to most likely stem from progression of her cancer. She was treated symptomatically for nausea and delirium, but continued to decline, developing diaphoresis, decreased level of consciousness, increased weakness, and lethargy. Further history revealed that over several weeks prior to admission her appetite had declined with minimal intake except for five to six cans of a 16 fluid ounce sugar-free ED daily.

On day 3, laboratory tests revealed significant hepatic and renal dysfunction. Baseline kidney and liver tests had been within normal range 2 months previously, except for mildly elevated alkaline phosphatase (ALP) (Table 1). A chest X-ray showed no acute cardiopulmonary disease. She received hydration with normal saline, empiric treatment of infection with ceftriaxone because of elevated white blood cell (WBC) count, and her home medications were adjusted for liver and kidney functions. Repeat laboratory tests on day 6 showed slightly improved liver but worsening renal function (Table 1). A urine culture was negative, and WBC normalized. Ultrasound revealed normal liver echogenicity, normal gallbladder with wall thickness $2 \mathrm{~mm}$, mild extrahepatic and intrahepatic duct dilatation (seen on previous imaging), and normal kidneys.

The family confirmed our patient's wishes to avoid transfer to the hospital or aggressive interventions such as dialysis or further intravenously administered antibiotics and was accepting of the possibility of limited prognosis. Supportive care was provided with hydration, parenteral medications, and symptom management. On days 8-9, she became more alert and began to take food, fluids, and medications reliably by mouth. Repeat laboratory tests on day 10 showed significant improvement consistent with her clinical condition with normal renal function and greatly improved liver enzymes. She returned to her baseline mental and functional status and was discharged home on day 14 with instructions to avoid further consumption of any ED products.

\section{Discussion}

As patients enrolled in hospice care begin to decline they often seek ways to improve or maintain hydration. EDs differ from "sport drinks" which provide hydration and replete electrolytes [3]. EDs contain high levels of carbohydrates, which affect fluid absorption and cause gastrointestinal distress, and they contain caffeine, which causes diuresis leading to increased urinary output and natriuresis instead of hydration [3]. Unfortunately, there are limited studies about the long-term effects of ED ingredients in humans [3]. Table 2 lists the ingredients in the ED consumed by our patient, who was drinking five to six cans (10-12 servings) per day.

Our patient appeared to develop AKI and AH simultaneously. She denied use of herbal supplements or alcohol;

Table 2 Energy drink ingredients

\begin{tabular}{ll}
\hline & Per serving $(8 \mathrm{oz}$. or $240 \mathrm{ml})$ \\
\hline Taurine & $1000 \mathrm{mg}$ \\
Guarana seed extract & $100 \mathrm{mg}$ \\
Glucuronolactone & $80 \mathrm{mg}$ \\
L-carnitine & $50 \mathrm{mg}$ \\
B8 (inositol) & $25 \mathrm{mg}$ \\
B3 (niacin) & $25 \mathrm{mg}$ \\
B6 & $20 \mathrm{mg}$ \\
B12 (cyanocobalamin) & $2 \mathrm{mg}$ \\
B2 (riboflavin) & $2 \mathrm{microgram}$ \\
B5 (pantothenic acid) & $3.4 \mathrm{mg}$ \\
\hline
\end{tabular}


Table 3 Summary of literature on the adverse effects of energy drink consumption

\begin{tabular}{|c|c|c|}
\hline Reference & Case summary & Conclusion \\
\hline $\begin{array}{l}\text { 1- Schöffl et al., } \\
2011[4]\end{array}$ & $\begin{array}{l}\text { According to Schöffl et al., Lehtihet } \mathrm{M} \text { et al. in } 2006 \text { reported } \\
\text { the case of a 31-year-old football referee who consumed EDs } \\
(750 \mathrm{ml}) \text { and developed AKl }\end{array}$ & Acute tubular necrosis and rhabdomyolysis \\
\hline $\begin{array}{l}\text { 2-Schöffl et al., } \\
2011[4]\end{array}$ & $\begin{array}{l}\text { A } 17 \text {-year-old boy consumed } 3 \mathrm{~L} \text { of EDs with } 1 \mathrm{~L} \text { of vodka } \\
\text { ( } 4600 \mathrm{mg} \text { of taurine, } 780 \mathrm{mg} \text { caffeine, and } 380 \mathrm{~g} \text { of alcohol) with AKI }\end{array}$ & $\begin{array}{l}\text { Taurine accumulation. AKI resolved in } 10 \text { days but } \\
\text { required hemodialysis }\end{array}$ \\
\hline $\begin{array}{l}\text { 3-Greene et al., } \\
2014[5]\end{array}$ & $\begin{array}{l}\text { A 40-year-old man consumed 100-120 oz. of EDs daily for 2-3 } \\
\text { weeks. Presented with hypoglycemia and AKI (creatinine } 5.5 \mathrm{mg} / \mathrm{dL} \text { ) }\end{array}$ & $\begin{array}{l}\text { Taurine accumulation, creatinine returned to normal } \\
\text { after } 2 \text { days of ED discontinuation }\end{array}$ \\
\hline $\begin{array}{l}\text { 4-Vivekanandarajah et al., } \\
2011 \text { [6] }\end{array}$ & $\begin{array}{l}\text { A } 22 \text {-year-old woman consumed ten cans of an energy drink daily } \\
\text { for } 2 \text { weeks and presented with } \mathrm{AH} \text {. On presentation, AST, ALT, and } \\
\text { total bilirubin were } 7709 \mathrm{U} / \mathrm{l}, 7533 \mathrm{U} / \mathrm{l}, 3.5 \mathrm{mg} / \mathrm{dL} \text { and on discharge } \\
\text { day } 4 \text { they were } 238 \mathrm{U} / \mathrm{l}, 1947 \mathrm{U} / \mathrm{l} \text {, and } 1.7 \mathrm{mg} / \mathrm{dL} \text {, respectively }\end{array}$ & $\begin{array}{l}\text { Hepatotoxicity was believed related to ED } \\
\text { consumption, which included niacin } 300 \mathrm{mg} / \text { day }\end{array}$ \\
\hline $\begin{array}{l}\text { 5-Huang et al., } \\
2014[7]\end{array}$ & 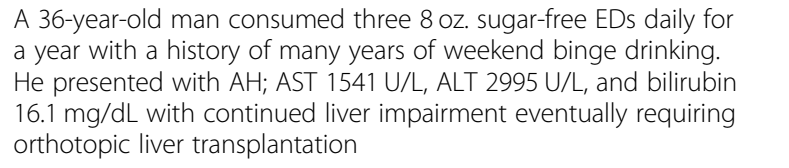 & $\begin{array}{l}\text { Liver biopsy consistent with herbal/drug toxicity. } \\
\text { Niacin dose was only } 120 \mathrm{mg} \text { per day }\end{array}$ \\
\hline $\begin{array}{l}\text { 6-Harb et al., } \\
2016[8]\end{array}$ & $\begin{array}{l}\text { A } 50 \text {-year-old man consumed four to five EDs ( } 40 \text { mg of niacin } \\
\text { each) per day over } 3 \text { weeks. He presented with } \mathrm{AH} \text {; AST } 4051 \mathrm{U} / \mathrm{L} \text {, } \\
\text { AST } 2073 \mathrm{U} / \mathrm{L} \text {, bilirubin } 19.3 \mathrm{mg} / \mathrm{dL} \text {. He improved after discontinuation } \\
\text { of EDs }\end{array}$ & $\begin{array}{l}\text { Liver biopsy showed severe acute hepatitis with } \\
\text { bridging necrosis and marked cholestasis. Daily } \\
\text { intake of niacin was approximately 160-200 mg }\end{array}$ \\
\hline
\end{tabular}

$A H$ acute hepatitis, $A K l$ acute kidney injury, $A L T$ alanine aminotransferase, $A S T$ aspartate aminotransferase, EDs energy drinks

she said she had previously tested negative for viral hepatitis, had no new medications or recent imaging with contrast, and was not on nephrotoxic medications. Her strongest risk factor was her daily consumption of large amounts of EDs. Based on a review of the literature (Table 3), the main contributor to AKI was most probably taurine, and, for $\mathrm{AH}$, niacin, although other ingredients or combinations of ingredients may also have played a role.

Taurine is a sulfur-containing amino acid typically used as a nutritional supplement by athletes to increase performance. There are some data from Suliman et al. suggesting increased risk from taurine intake in patients with renal failure who develop neurological symptoms [9]. Suliman et al. also recommend avoiding EDs in these patients [9]. Our patient consumed 10-12 g/day.

Niacin (vitamin B3) can cause hepatotoxicity at doses between 1 and $5 \mathrm{~g} /$ day [10]. The laboratory pattern of liver injury due to drugs or toxins could be hepatocellular, cholestatic, or mixed [11]. AH has been described in several cases at lower levels of niacin consumption as a component of EDs at levels similar to our patient who consumed between 200 and $240 \mathrm{mg} /$ day.

\section{Conclusion}

To the best of our knowledge this is the first reported case of simultaneous ED induced AKI and AH. Until more research reveals safe amounts of EDs and their ingredients, excessive use should be avoided and a thorough history should include questions regarding supplements including beverages such as EDs which are perceived as safe.
Abbreviations

AH: Acute hepatitis; AKI: Acute kidney injury; EDs: Energy drinks; WBC: White blood cell

\section{Acknowledgements}

Not applicable.

\section{Authors' contributions}

$\mathrm{RA}, \mathrm{DL}$, and CK designed the research paper, and collected and analyzed data. RA wrote the paper. The paper was edited by DL and CK. RA had primary responsibility for the final content. All authors read and approved the final manuscript. RA's workplace change: currently University of Florida, Gainesville, FL.

\section{Funding}

No financial support was utilized in preparation of this manuscript.

\section{Availability of data and materials}

All the data supporting our findings is contained within the manuscript.

\section{Ethics approval and consent to participate}

Ethics committee approval was not applicable as the information was analyzed in a retrospective manner and had no effect on treatment.

\section{Consent for publication}

Written informed consent was obtained from the patient for publication of this case report and any accompanying images. A copy of the written consent is available for review by the Editor-in-Chief of this journal.

\section{Competing interests}

The authors declare that they have no competing interests.

\section{Author details}

'Division of Hospital Medicine, Department of Internal Medicine, University of Florida, 1230 SW 11th Ave, C405, Gainesville, FL 32601, USA. Division of Geriatric and Palliative care, Department of Internal Medicine, University at Buffalo, Buffalo, NY, USA. ${ }^{3}$ The Center for Hospice \& Palliative Care,

Cheektowaga, NY, USA. 
Received: 7 December 2019 Accepted: 30 December 2019

\section{1.}

\section{References}

1. Vercammen KA, Koma JW, Bleich SN. Trends in Energy Drink Consumption Among U.S. Adolescents and Adults, 2003-2016. Am J Prev Med. 2019; https://doi.org/10.1016/j.amepre.2018.12.007.

2. FDA website: http://wayback.archive-it.org/7993/20171114232636/https:// www.fda.gov/Food/RecallsOutbreaksEmergencies/SafetyAlertsAdvisories/ ucm328536.htm.

3. Higgins JP, Tuttle TD, Higgins CL. Energy beverages: content and safety. Mayo Clin Proc. 2010;85:1033.

4. Schöffl I, Kothmann JF, Schöffl V, Rupprecht HD, Rupprecht T. "Vodka energy": too much for the adolescent nephron? Pediatrics. 2011;128(1): e227-31. https://doi.org/10.1542/peds.2010-2677. Epub 2011 Jun 13

5. Greene E, Oman K, Lefler M. Energy drink-induced acute kidney injury. Ann Pharmacother. 2014;48(10):1366-70. https://doi.org/10.1177/ 1060028014541997. Epub 2014 Jul 1

6. Vivekanandarajah A, Ni S, Waked A. Acute hepatitis in a woman following excessive ingestion of an energy drink: a case report. J Med Case Rep. 2011; 5:227. https://doi.org/10.1186/1752-1947-5-227.

7. Huang B, Kunkel D, Kabany ME. Acute Liver Failure Following One Year of Daily Consumption of a Sugar-Free Energy Drink. ACG Case Rep J. 2014; (4): 214-6. https://doi.org/10.14309/cri.2014.57. eCollection 2014 Jul

8. Harb JN, Taylor ZA, Khullar V, Sattari M. Rare cause of acute hepatitis: a common energy drink. BMJ Case Rep. 2016;2016 https://doi.org/10.1136/ bcr-2016-216612.

9. Suliman ME, Bárány P, Filho JC, Lindholm B, Bergström J. Accumulation of taurine in patients with renal failure. Nephrol Dial Transplant. 2002;17(3): 528-9.

10. Rizakallah GS, Mertens MK, Brown ML, Sanner L. Clinical inquiries: should liver enzymes be checked in a patient taking niacin? J Fam Pract. 2005;54: 265-8.

11. Chang CY, Schiano TD. Review article: drug hepatotoxicity. Aliment Pharmacol Ther. 2007;25(10):1135-51.

\section{Publisher's Note}

Springer Nature remains neutral with regard to jurisdictional claims in published maps and institutional affiliations.

Ready to submit your research? Choose BMC and benefit from:

- fast, convenient online submission

- thorough peer review by experienced researchers in your field

- rapid publication on acceptance

- support for research data, including large and complex data types

- gold Open Access which fosters wider collaboration and increased citations

- maximum visibility for your research: over $100 \mathrm{M}$ website views per year

At $\mathrm{BMC}$, research is always in progress.

Learn more biomedcentral.com/submissions 